\title{
SPATIAL FORMATION OF WATER PROTECTION ZONES ON THE AGRICULTURAL LAND
}

\author{
Tetiana Tairova \\ Victor Ladijenskiy \\ Kharkiv National Academy of Municipal Economy, Ukraine
}

\begin{abstract}
In recent years, increasing of the environmental awareness due to world water pollution has been growing. Integral part is a policy design as key element in water resources management. Paper elucidates the issue of surface water pollution by means of runoff from croplands. The purpose is to develop new design technique to determine the size of water protection zones (WPZs) and to devise the normative document on the WPZs design technique by means of geographic information systems (GIS).

All the calculations to be carried out in the project will be accomplished by means of GIS. GIS permit to predict and analyze developing and volume of water erosion in the study area, evaluate surface-water flow, depict catchments area.
\end{abstract}

\section{KEY WORDS}

Water protection zone; water erosion; USLE; geoinformation system (GIS).

\section{INTRODUCTION}

The coastal land is an important component in the environmental system, and plays a key role in rivers protection from pollution, maintenance of biodiversity, etc. The lands in question have been broken up to water's edge due to agricultural organizations cultivating. It is had led to heavy pollution, clogging and silting of surface water bodies. Runoff pollution has increased as result of such factors impact as water erosion, suspended and dissolved matters discharge from croplands, while watersheds being ploughed up.

Hereupon, degradation of small rivers and their disappearance as a landscape element has taken place. De to shoaling of small rivers, middle and big rivers have become shallow and silted up.

Moreover, the shallowing of rivers predetermined a chain reaction of negative environmental effects, namely, reduction of water content area, productivity ecosystems reduction and their capacity for self-purification, animals and plants species disappearance.

Water protection zone (WPZ) is an area of land, specifically designed to protect surface and underground water resources from pollution, contamination. It serves not for any anthropogenic use but as a conserved natural habitat where plants and animals can thrive. Hence, the water protection zones are necessary to minimize the impacts of an adjacent land

https://doi.org/10.15626/Eco-Tech.2010.042 
use. WPZs protect the natural environment and help keep nearby ecological niches stable and functioning [1].

In 1981, Ukrainian Scientific Research Institute of Ecological Problems published a normative document in which scholars described recommendations for WPZ design [8]. It was considered that quantitative measures would usefully supplement and extend the qualitative analysis.

A recent treatment by Samoylenko V. and Tavrov Y. (1997) has provided in-depth analysis of the most blatant contravention of standards and requirements. They are as follows:

- $\quad$ soil ploughing up to the waterline or shore (bank) ledge;

- location of agricultural activity directly in the waterside zone;

- $\quad$ omission of simple biotechnical measures, such as bank forest shelter belts, etc.;

- $\quad$ herding of animals in the area close to the banks which causes deterioration in landscape stability through destruction and disturbance of the vegetation cover;

- $\quad$ waterside dumping as a result of the fertilizer storage, uncivilized recreation and other negative environmental consequences of local economic and social activity. [4]

In recent years, there has been an increasing amount of literature on issue of river protection from contamination. According to Radionov G. et al. (2006), using geoinformation system (GIS) as a component of WPZ design technique is far more appropriate and therefore, better adjusted to the developing world [9].

In 2004, Yatsik A. et al. proposed a new and convenient system of procedures to obtain the proper size for buffer zone [13]. However, a serious weakness of the method is that an upper bound of water protection zone is formed on the assumption of virgin and long-fallow lands developing next to riverside.

\section{STUDY AREA AND SITE DESCRIPTION}

A river called Nemyshlya has situated in Kharkiv region in Ukraine. The river heads in south of the village Mikhajlovka and flows into the river Kharkiv. River has been running along rural areas of such settlements as: Frunze, Prelestnoe, Brajniki and Kulynychi. The catchment area is $72,2 \mathrm{~km}^{2}$, the length of the river is $23 \mathrm{~km}$ and average gradient is $4,8 \%$ (see Figure 1, 2).

The Nemyshlya Valley is deep, slightly has been indented by ravines and has a prominent Ushape. Slopes are comparative gentle and asymmetric. In most cases they have been cultivated.

The high-water bed developed, a width of the river is $70 \mathrm{~m}$. The valley has been gaining in breadth up to more than $2 \mathrm{~km}$. Surface is waterlogged. The Nemyshlya stream canal is within view from the village Brazhniki. Here, in flood-lands, phreatic rise as a spring are observed. Further, the riverbed is lost to view in the valley to has overgrown with carex. In summer the water is stored only in the lowest places $[7,10]$. 


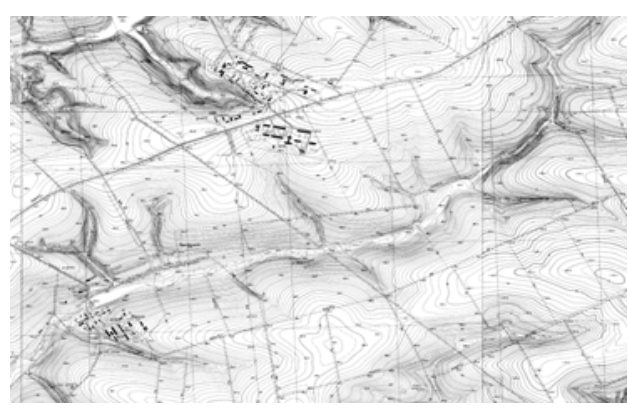

Figure 1. A plotting device M 1:10000. Figure 2. An aerial photograph of the Nemyshlya valley.

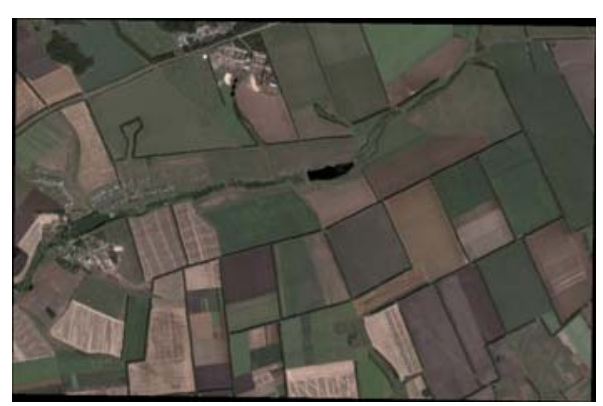

\section{METHODS}

The upper boundary of WPS to be determined should evaluate the long term average annual rate of erosion on a field slope. The methodology to use in the paper its implementation of the Universal Soil Loss Equation (USLE) in a raster GIS environment.

The GIS enable to depict the surface under consideration, to estimate the characteristic properties of the soil cover and land use. It creates favourable conditions for adequate mapping of the erosive factors spatial variations and other processes to occur in landscapes and agrolandscape systems.

Five fundamental factors will be applied practically to evaluate the soil loss for a given site. Each factor is the numerical estimate of a specific condition that affects the severity of soil erosion at a particular location [5]. For the simulating of spatial model for soil erosion assessment, USLE model will be pursued under GIS environment for different watersheds. The several thematic layers required for the model simulation will be generated by means of GIS. These thematic layers for applying in USLE model are rainfall erosivity factor, soil erosivity factor, slope length factor, slope steepness factor, vegetative cover and management factor and erosion control practice factor $[2,3]$.

\subsection{Calculation of annual soil loss}

Annual soil loss was calculated on a spatial basis using the Universal Soil Loss Equation (USLE) as follows:

$\mathrm{A}=\mathrm{R} * \mathrm{~K} * \mathrm{~L} * \mathrm{~S} * \mathrm{C} * \mathrm{P}$

where $A$ - average annual soil loss (t/ha/y) $R$ - index of rain erosivity, $K$ - index of soil erodibility, $L$ and $S$ - topographical factors, $C$ - land cover and management factor, and $P$ conservation practice (support) factor.

The mathematic model enables to predict and to analyse the water erosion differentiation. Consequently, classification of the soil loss tolerance rates to be occurred.

Erosivity index (R) was calculated from rainfall data has been obtained by Research Institution of Soil Conservation, $K$ factor was collected by National scientific centre of the 
husbandry UAAC [12], $L$ and $S$ factors were obtained from Digital Elevation Model (DEM) (see Figure 3), $C$ and $P$ factors were calculated from land use map.

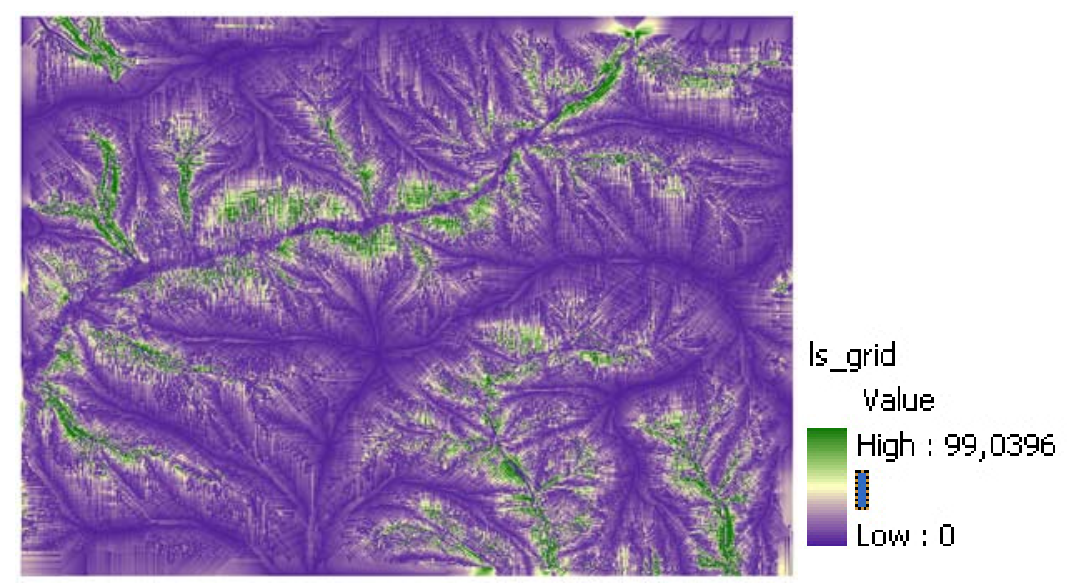

Figure 3. Product of the L and S factors.

\subsection{WPZ plotting}

Each erosion factor was generated in a rater GIS data layer. Further, annual soil loss was calculated for each watershed. We focused our attention on moderate (see Figure 4), high and severe rate of soil losses. Moreover, the range of annual soil losses has been selected on account of impact for environment (see Table 1).

Table 1. Soil Loss Tolerance Rates.

\begin{tabular}{|c|c|c|}
\hline Soil Erosion Class & $\begin{array}{l}\text { Potential Soil Loss } \\
\text { (tons/ hectare/year) }\end{array}$ & 845 \\
\hline $\begin{array}{l}\text { Very Low } \\
\text { (tolerable) }\end{array}$ & $<0.5$ & \\
\hline Low & $0.5-1.0$ & \\
\hline Moderate & $1.0-5.0$ & \\
\hline High & $5.0-10.0$ & \\
\hline Severe & $>10.0$ & Figure 3. Annual soil loss $A=5 \mathrm{t} / \mathrm{ha} / \mathrm{y}$ \\
\hline
\end{tabular}

\section{RESULTS AND DISCUSSIONS}

The most obvious finding to emerge from this study is that non-point source pollutions haven't examined by governmental monitoring and control system. The study has gone some way towards enhancing our understanding of water protection value.

Results were obtained on the basis of environmental information processing by means of GIS. In most studied cases moderate, high and severe rate of soil losses have been revealed. On the 
ground of the date to have been obtained the water protection zone for the Nemyshlya was designed according to the degree of water erosion risk of the area (see Figure 5, 6). Developing and improving the design technique is assumed to reduce average annual rate of erosion; maintenance of biodiversity; refine the fresh water in rivers.

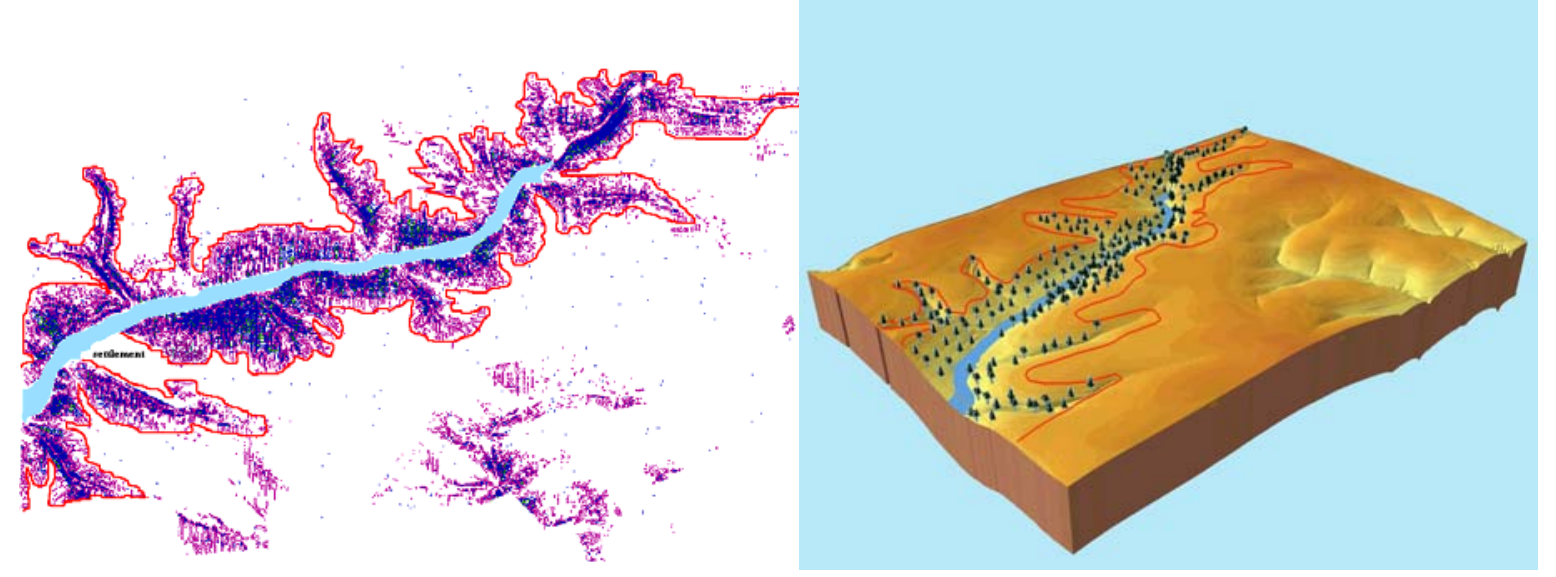

Figure 5 .The water protection zone.

Figure 6. 3D model of the water protection zone.

\section{CONCLUSIONS}

The first step of WPZs spatial formation methodology was elucidated. The designing technique for buffer zones of rivers should be performed on account of natural and geographical conditions of the costal land. This research has thrown up many questions in need of further investigation. Further experimental investigations are needed to estimate the runoff from croplands and to treat the role of the riparian forest and phytotechnology for achieving best results of the rivers protection.

\section{REFERENCES}

[1] Ecological buffer zone. [Electronic resource]. URL: http://www.biologyonline.org/dictionary/Ecological buffer zone (online)

[2] Implementation of USLE Model Under GIS Environment for Soil Erosion Assessment: A case study of Loni River Watershed. [Electronic resource]. URL: http://www.mapindia.org/2005/papers/Water\%20Resources\%20I/265abs.htm(online)

[3] Multi-temporal soil erosion risk assessment in N. Chalkidiki using a modified USLE raster model. [Electronic resource]. URL: http://www.eproceedings.org/static/vol08 1/08 1 gitas1.pdf(online)

[4] V. Samoylenko, Y. Tavrov. The establishment of water protection zones for water quality improvement in river basins. // Freshwater Contamination (Proceedings of Rabat Symposium S4, April-May 1997). 1997. - № 243. [Electronic resource]. URL: http://iahs.info/redbooks/a243/iahs 243 0385.pdf

[5] Universal Soil Loss Equation (USLE). [Electronic resource]. URL: http://www.omafra.gov.on.ca/english/engineer/facts/00-001.htm (online)

[6] Заславский М. Н. Эрозиовидение. Основы противоэрозионного земледелия. - М.: Высшая школа. - 1987. - 376с. 
[7]

Немышля.

[Electronic

resource].

URL:

http://ru.wikipedia.org/wiki/\%D0\%9D\%D0\%B5\%D0\%BC\%D1\%8B\%D1\%88\%D0\%BB\%D $1 \% 8 \mathrm{~F} \% 28 \% \mathrm{D} 1 \% 80 \% \mathrm{D} 0 \% \mathrm{~B} 5 \% \mathrm{D} 0 \% \mathrm{BA} \% \mathrm{D} 0 \% \mathrm{~B} 0 \% 29$ (online)

[8] Постановление совета министров РСФСР от 14 января 1981г. №28.

[9] Проектирование водоохранных зон с применением ПО ESRI [Электронный ресурс]. URL:http://www.dataplus.ru/arcrev/Number 36/14 zone2.html (дата обращения: 28 Мау 2010)

[10] Река Немышля. [Electronic resource]. URL: http://kpvoda.kharkov.ua/index.php/content/about/today/waterresources/nemishlya_river/ (online)

[11] Вінніченко К. А., Таірова Т. Г., Кучеренко С. І., Ладиженський В. М.. 2009. Формування водоохоронних зон водних об'єктів з застосуванням геоінформаційних технологій.// Восточно-Европейский журнал передовых технологий. - № 2/4(38). Харьков, С. $44-46$.

[12] Кривов В. М. 2006. Екологічно безпечне землекористування Лісостепу України. Проблема охорони грунтів. - К.: Урожай,. С. 277-280.

[13] Методика упорядкування водоохоронних зон річок України. - К.: Оріяни, 2004. $128 \mathrm{c}$.

[14] Таірова Т. Г., Ладиженський В. М. 2009. Проектування водоохоронних зон річок за допомогою ГІС.//Екологічний менеджмент у загальній системі управління. Збірник тез Дев’ятої Щорічної Всеукраїнської конференції.Частина 2. Вид-во Сумського Державного Університету, С. 110-112. 